\title{
Reikwijdte van de buitencontractuele aansprakelijkheid van de accountant bij de uitoefening van een niet- wettelijke taak
}

\author{
Bespreking van HR 29 januari 2021, ECLI:NL:HR:2021:149 (Sloepenbedrijf) \\ Mr. G.A.J. Boekraad*
}

\begin{abstract}
1 Inleiding
In januari van dit jaar boog de Hoge Raad zich over de mogelijke aansprakelijkheid van een accountant bij de uitoefening van een niet-wettelijke taak jegens andere partijen dan zijn opdrachtgever.
\end{abstract}

Naar haar aard is dat lastige materie. Enerzijds speelt het uitgangspunt dat contractspartijen contracteren met het oog op hun eigen belangen en dat zij zich pas iets gelegen hoeven laten aan de belangen van andere partijen voor zover de in het maatschappelijk verkeer in acht te nemen zorgvuldigheid dat vereist. Anderzijds is het een maatschappelijke realiteit dat partijen een bepaalde mate van vertrouwen ontlenen aan de rapportages van een accountant. ${ }^{1}$ Dat geldt ook voor andere partijen dan die in opdracht waarvan de accountant een rapportage heeft opgesteld (derden). De accountant wordt gezien als een deskundige die objectief, op basis van eigen onderzoek, tot bevindingen komt. Daarbij speelt een rol dat de wetgever sommige taken, zoals de controle van jaarrekeningen van rechtspersonen van een bepaalde aard of omvang, exclusief aan de accountant heeft toevertrouwd, juist vanwege zijn deskundigheid en objectiviteit. Dat brengt bijzondere verantwoordelijkheden met zich bij de vervulling van die specifieke wettelijke taken. Het draagt er echter ook aan bij dat wanneer de accountant een taak vervult die wettelijk niet aan hem is voorbehouden, ook daaraan een zeker vertrouwen kan worden ontleend, ook door derden.

In de kern is dat de reden waarom in de rechtspraak wordt aangenomen dat de accountant ook bij de vervulling van nietwettelijke taken onder omstandigheden een zorgplicht jegens

\footnotetext{
Mr. G.A.J. Boekraad is advocaat bij Stibbe te Amsterdam.

1. E.J.A.M. van den Akker, Beroepsaansprakelijkheid ten opzichte van derden (diss. Tilburg), Den Haag: Boom Juridische uitgevers 2001, p. 74-75.
}

bepaalde derden kan hebben. De vraag is dan natuurlijk: onder welke omstandigheden en jegens welke derden? Die vragen laten zich niet gemakkelijk met een paar abstracte regels beantwoorden. Het is casuïstische problematiek, waarbij de rechter van geval tot geval grenzen moet trekken en waarover per definitie valt te twisten. Dat wordt bevestigd door het arrest van de Hoge Raad van 29 januari 2021, dat de aanleiding vormt voor deze bijdrage. De Hoge Raad passeert het advies van de advocaat-generaal om een veel ruimere reikwijdte toe te kennen aan de buitencontractuele aansprakelijkheid (de aansprakelijkheid jegens derden dus) van de in de casus betrokken accountants bij de uitoefening van een nietwettelijke taak dan door de rechters in feitelijke instanties was aangenomen.

Voordat ik inga op de concrete zaak, zal ik eerst in grote lijnen het huidige kader schetsen voor de beoordeling van de civielrechtelijke aansprakelijkheid van de accountant jegens derden.

\section{Civielrechtelijke aansprakelijkheid van de accountant jegens derden}

Bij de vraag naar de civielrechtelijke aansprakelijkheid van de accountant is het van belang onderscheid te maken: aansprakelijkheid jegens wie en met betrekking tot welk type werkzaamheden?

\subsection{Contractuele versus buitencontractuele aansprakelijkheid}

Een eerste vraag is dan of het gaat om aansprakelijkheid jegens de opdrachtgever of jegens een derde. Jegens de opdrachtgever heeft de accountant vanzelfsprekend een zorgplicht; hij moet de zorg van een goed opdrachtnemer in acht nemen (art. 7:401 BW). Volgens vaste rechtspraak dient een accountant bij de uitvoering van zijn opdracht de zorgvuldigheid in acht te nemen die van een redelijk bekwame en redelijk hande- 
lende vakgenoot mag worden verwacht. ${ }^{2}$ Het komt hierbij aan op een beoordeling van alle omstandigheden van het geval. Daarbij is onder meer van belang of de accountant heeft gehandeld in overeenstemming met de normen en standaarden die in zijn beroepsgroep algemeen worden aanvaard, waaronder de gedrags- en beroepsregels.

Onder bijzondere omstandigheden kan schending van de contractuele zorgplicht tevens een onrechtmatige daad jegens derden opleveren. Dat is onder meer afhankelijk van de hoedanigheid van de betrokken partijen, de aard en de strekking van de desbetreffende overeenkomst, de wijze waarop de derde bij de overeenkomst is betrokken, en de aard en de omvang van het nadeel dat voor hem dreigt. ${ }^{3}$ Situaties waarin de contractuele zorgplicht zich op die gronden mede uitstrekt tot een derde, zijn in het maatschappelijk verkeer evenwel uitzonderlijk.

Daarnaast kan een partij bij de uitvoering van een contract een zorgplicht hebben jegens een derde die geheel losstaat van haar contractuele zorgplicht. Ook dat is echter de uitzondering. Uitgangspunt blijft immers dat partijen louter met het oog op hun eigen belangen contracteren. Contractspartijen behoeven zich in beginsel slechts om belangen van derden te bekommeren voor zover dat wordt vereist door hetgeen in het maatschappelijk verkeer betaamt (art. 6:162 lid 2 BW). De bijzondere positie die de accountant in het maatschappelijk verkeer inneemt, is in dat verband relevant. Dat makt dat een accountant over het algemeen eerder rekening moet houden met de belangen van derden dan een willekeurige andere contractspartij. Het maakt daarbij natuurlijk wel uit welk type werkzaamheden de accountant bij de uitvoering van een opdracht verricht. In het bijzonder is dan van belang of het gaat om de vervulling van een taak die wettelijk aan de accountant is voorbehouden, of om de uitvoering van een nietwettelijke taak.

\subsection{Aansprakelijkheid jegens derden bij de uitoefening van wettelijke taken}

De wettelijk voorgeschreven controle van jaarrekeningen van onder meer middelgrote en grote ondernemingen moet op grond van art. 2:393 BW door een accountant plaatsvinden. Andere voorbeelden van wettelijk aan de accountant toebedeelde taken zijn: de afgifte van de verklaring over ruilverhoudingen bij fusies ${ }^{4}$ en splitsingen, ${ }^{5}$ de inbrengverklaring ${ }^{6}$ en de verklaring bij omzetting van een BV naar een NV. ${ }^{7}$ Sinds kort

2. Zie voor een vrij recent voorbeeld van een zaak waarin een accountant op deze contractuele grondslag aansprakelijk werd geacht jegens zijn opdrachtgever: HR 27 september 2019, ECLI:NL:HR:2019:1447 (afgedaan met toepassing van art. $81 \mathrm{Wet}$ RO).

3. HR 24 september 2004, ECLI:NL:HR:2004:AO9069 (Vleesmeesters Versman/Alog).

4. Art. 2:328 BW.

5. Art. 2:334aa BW.

6. Art. 2:94a lid 2 en 2:204a lid 2 BW.

7. Art. 2:72 BW. kan ook worden gedacht aan de accountantsverklaring die wordt voorgeschreven bij toepassing van de NOW-subsidie. ${ }^{8}$

Dat de accountant bij de uitvoering van een wettelijke taak een zorgplicht jegens derden kan hebben, ligt voor de hand. Het gaat dan immers om een taak die maatschappelijke relevantie heeft en die daarom wettelijk is voorgeschreven. In die gevallen is duidelijk dat de accountant niet alleen het belang van zijn opdrachtgever dient, maar ook een publiek belang. Niet iedere geschonden norm leidt echter direct tot aansprakelijkheid jegens derden. In het Vie d'Or II-arrest ${ }^{9}$ heeft de Hoge Raad het kader geschetst voor de wijze waarop in verband met de uitoefening van de wettelijke controletaak de aansprakelijkheid van de accountant jegens derden - gebruikers van de jaarrekening - moet worden beoordeeld.

De maatstaf die de Hoge Raad daarbij (weer) vooropstelt, is die van de redelijk handelende en redelijk bekwame externe controlerend accountant. Bij de beantwoording van de vraag of de externe controlerend accountant heeft gehandeld in overeenstemming met de van hem in het concrete geval te vergen mate van zorg, komt het aan op een beoordeling van alle omstandigheden van het geval. Vervolgens schetst de Hoge Raad een aantal factoren die daarbij in aanmerking moeten worden genomen. Eén van die factoren is de vraag in hoeverre de accountant bij zijn controlewerkzaamheden de relevante verslaggevingsregels in aanmerking heeft genomen. Andere door de Hoge Raad genoemde factoren zijn: de aard van de geschonden norm en de ernst van de geconstateerde schending daarvan, de door de accountant wel getroffen maatregelen of verschafte informatie, de mate waarin het gevaar van schade door aantasting van de in het geding zijnde vermogensbelangen voor de accountant redelijkerwijs voorzienbaar was, en - mede in verband daarmee - of die (controle)maatregelen zijn genomen en die waarschuwingen zijn gegeven die in de gegeven omstandigheden redelijkerwijs van de accountant konden worden gevergd ter voorkoming van dit gevaar. ${ }^{10}$

Uit het feit dat de Hoge Raad in het Vie d'Or II-arrest in algemene zin en zonder beperking spreekt van 'derden', leidt NJannotator Van Dam af dat de hier bedoelde zorgplicht van de externe controlerend accountant zou strekken tot bescherming van een onbeperkte groep derden, ongeacht of deze voorzienbaar zijn en ongeacht de hoogte van hun schade. De enige beperking zou volgens Van Dam zijn dat het moet gaan om derden die bij hun beslissingen zijn afgegaan op de door de beroepsbeoefenaar verschafte informatie. ${ }^{11}$ Anderen menen dat dit niet uit het arrest kan worden afgeleid en zijn van oor-

8. Zie o.a. art. 13 lid 2 Eerste tijdelijke noodmaatregel overbrugging voor behoud van werkgelegenheid (kort gezegd: NOW).

9. HR 13 oktober 2006, ECLI:NL:HR:2006:AW2080 (Vie d'Or II).

10. HR 13 oktober 2006, ECLI:NL:HR:2006:AW2080 (Vie d'Or II), r.o. 5.4.2.

11. C.C. van Dam, annotatie bij het Vie d'Or II-arrest in NJ 2008/529, nr. 5 . 


\section{Maandblad}

deel dat van een (zo) onbegrensde zorgplicht jegens alle mogelijke derden geen sprake kan zijn. ${ }^{12}$

Jegens welke derden een zorgplicht van de externe controlerend accountant bestaat, hangt onder meer af van hoe concreet voorzienbaar het door de Hoge Raad bedoelde gevaar van schade bij derden moet zijn. Zou een louter abstracte benadering van deze vraag al voldoende zijn, dan zou dit gezichtspunt weinig toegevoegde waarde hebben: in algemene zin zal het voor de externe controlerend accountant duidelijk zijn dat derden kennis zullen kunnen nemen van de door hem gecontroleerde jaarrekening en mede daarop beslissingen kunnen baseren. Blaisse wijst erop dat de door de Hoge Raad gebruikte terminologie 'redelijkerwijs voorzienbaar' op het eerste gezicht duidt op een dergelijke geobjectiveerde invulling, maar dat de verwijzing door de Hoge Raad naar getroffen maatregelen en gegeven waarschuwingen juist weer duidt op een meer subjectieve invulling. Die verwijzing lijkt te impliceren dat de accountant ten tijde van de controlewerkzaamheden ermee bekend moet zijn welke concrete belangen van derden aan de orde zijn, zodat hij zijn gedrag daarop kan afstemmen door het treffen van maatregelen en geven van waarschuwingen. ${ }^{13}$ Blaisse neemt aan dat de door de Hoge Raad genoemde gezichtspunten niet limitatief zijn. Hij noemt het voorbeeld van de hoedanigheid van de derde, een factor die door de Hoge Raad niet wordt genoemd, maar die volgens hem evenzeer een relevant gezichtspunt kan zijn. ${ }^{14}$ Het verschil tussen bijvoorbeeld een particuliere belegger en een professionele instelling kan in een concreet geval groot zijn. De mate van professionaliteit van een gebruiker van de jaarrekening kan aanleiding geven de geleden schade geheel of gedeeltelijk voor zijn eigen rekening te laten komen op grond van eigen schuld (art. 6:101 BW). ${ }^{15}$ Het kan onder omstandigheden echter ook bijdragen aan het oordeel dat van schending van een geschonden zorgvuldigheidsnorm jegens die gebruiker geen sprake is, bijvoorbeeld als de professionaliteit van de gebruiker van invloed is op wat voor de accountant

12. Zie bijv. T.F.E. Tjong Tjin Tai, Zorgplichten en zorgethiek (diss. Amsterdam UvA), Deventer: Kluwer 2007, p. 208. Zie ook J.B.S. Hijink, Aansprakelijkheid van controlerend accountants, in: D. Busch e.a. (red.), Aansprakelijkheid in de financiële sector (Serie Onderneming en Recht, deel 78), Deventer: Kluwer 2013, par. 22.5.3.

13. H.J. Blaisse, De reikwijdte van de derdenaansprakelijkheid van de accountant, Ondernemingsrecht 2013/3, onder nr. 6 .

14. Blaisse 2013, onder nr. 7.

15. Zie voor een voorbeeld daarvan Hof Amsterdam 6 februari 2003, JOR 2003/93 (Van Lanschot/KPMG). Van Lanschot stelde bij een kredietverstrekking op door KPMG gecontroleerde jaarrekeningen te hebben vertrouwd, maar moest haar schade geheel zelf dragen omdat zij haar eigen onderzoeksplicht had verzaakt. Zie hierover J.E. Brink-van der Meer, Accountantsaansprakelijkheid (Serie Recht en Praktijk, nr. CA20), Deventer: Wolters Kluwer 2018, par. 5.6.1.3. voorzienbaar was. ${ }^{16}$ Hijink zoekt de limitering van de derdenaansprakelijkheid van de controlerend accountant vooral in de vraag of en in welke mate een derde zich voor het nemen van zijn beslissingen kon baseren op de jaarrekening en de daarbij gevoegde accountantsverklaring, en de daaraan ten grondslag liggende controlewerkzaamheden. Hij wijst erop dat de jaarrekening lang niet altijd geschikt is om tal van investeringsbeslissingen te nemen. ${ }^{17}$

Men kan zich afvragen hoe de door de Hoge Raad in het Vie d'Or II-arrest genoemde factoren zich verhouden tot de relativiteitseis van art. 6:163 BW. Het lijkt erop dat de Hoge Raad met een aantal van deze factoren (ik denk dan met name aan de aard van de geschonden norm en de voorzienbaarheid) mede invulling geeft aan dat vereiste voor aansprakelijkheid. Als het gaat om een onrechtmatige daad wegens strijd met hetgeen in het maatschappelijk verkeer betaamt, zoals hier het geval is, is het soms moeilijk om onderscheid te maken tussen de zorgvuldigheidsnorm zelf en de relativiteit. Dit komt doordat een ongeschreven norm van geval tot geval wordt aangenomen en daardoor naar haar aard al betrekkelijk (lees: gerelativeerd) is. ${ }^{18}$ Anders gezegd: de zorgvuldigheidsnorm van art. 6:162 lid $2 \mathrm{BW}$ is in beginsel steeds specifiek en ziet op een bepaald concreet belang in een specifieke situatie. $\mathrm{Zij}$ gebiedt onder bepaalde omstandigheden met dat belang rekening te houden. ${ }^{19}$ Reeds daaruit volgt mijns inziens dat uit het Vie d'Or II-arrest niet kan worden afgeleid dat indien de externe controlerend accountant een ongeschreven zorgvuldigheidsnorm heeft geschonden, hij daarmee onrechtmatig heeft gehandeld jegens iedere willekeurige derde die daardoor op wat voor manier ook schade lijdt. Toetsing aan het relativiteitsvereiste betekent dat de rechter in ieder concreet geval beoordeelt of de desbetreffende accountant specifiek jegens de benadeelde in kwestie onrechtmatig heeft gehandeld. Daarbij komt het volgens de vaste maatstaf van de Hoge Raad aan op het doel en de strekking van de geschonden norm, aan de hand waarvan moet worden onderzocht tot welke personen en tot welke schade en welke wijzen van ontstaan van schade de daarmee beoogde bescherming zich uitstrekt. ${ }^{20}$

Kortom, het publieke karakter van de wettelijke controletaak rechtvaardigt in geval van een normschending bij de uitoefening van die takk zeker niet een onbegrensde reikwijdte

16. Vgl. Rb. Amsterdam 9 juni 1999, JOR 1999/195 in de zaak tussen Van Lanschot en KPMG (die in hoger beroep leidde tot het in noot 15 genoemde arrest van het gerechtshof Amsterdam). In r.o. 5.2 overweegt de rechtbank, kort weergegeven, dat de betrokken accountants niet behoefden te voorzien dat een erkende bankinstelling, uitsluitend afgaande op de jaarrekening en zonder eigen onderzoek naar de kredietwaardigheid, een groot krediet zou verstrekken aan een bedrijf in opbouw.

17. Hijink 2013, par. 22.5.3.

18. Zie Asser/Sieburgh 6-IV 2019/135.

19. Zie onder meer HR 2 december 1994, ECLI:NL:HR:1994:ZC1564, NJ 1995/288 (Poot/ABP), r.o. 3.4.3.

20. De laatste keer dat de Hoge Raad deze maatstaf noemde, was in HR 20 september 2019, ECLI:NL:HR:2019:1409, NJ 2020/233 (schietpartij Alphen aan den Rijn), r.o. 3.1.3. 
van de mogelijke aansprakelijkheid van de externe controlerend accountant jegens derden.

\subsection{Aansprakelijkheid jegens derden bij de uitoefening van niet-wettelijke taken}

Dan de niet-wettelijke taken van de accountant. Een bekend voorbeeld daarvan is de samenstellingsopdracht: de accountant ondersteunt in dat geval het bestuur bij het opstellen en presenteren van cijfers of financiële overzichten zonder dat de accountant daarbij assurance verleent. Dat wil zeggen dat geen zekerheid wordt gegeven over de juistheid of de volledigheid van de samengestelde gegevens. Andere voorbeelden van nietwettelijke taken zijn: waardebepalingen, allerlei vormen van advisering, (persoonsgerichte) onderzoeken naar onregelmatigheden of schadeberekeningen in het kader van aansprakelijkheidsgeschillen.

Bij het vervullen van dit soort niet-wettelijke taken speelt niet het perspectief van het publieke belang: dit soort werkzaamheden zijn naar hun aard niet op de belangen van derden gericht. Uitgangspunt is dan ook dat de accountant bij de vervulling van werkzaamheden die niet wettelijk zijn voorgeschreven geen zorgplicht jegens derden heeft. Dat kan onder omstandigheden echter anders zijn. Uit de rechtspraak en literatuur blijkt dat met name in twee gevalstypen sprake kan zijn van een zorgplicht van de accountant jegens derden bij de vervulling van een andere dan een wettelijke taak.

Het eerste gevalstype is dat waarin de positie van één of meer derden direct wordt beïnvloed door het werk van de accountant. Dat geldt met name bij persoonsgerichte onderzoeken, die naar hun aard kunnen leiden tot bevindingen ten aanzien van (de handelwijze van) een persoon. Gelet op de rol van objectieve deskundige die de accountant in het maatschappelijk verkeer vervult, heeft de accountant zich rekenschap te geven van het gewicht dat anderen aan zijn bevindingen kunnen hechten bij hun oordeelvorming over de desbetreffende persoon. Dat kan met zich brengen dat de accountant rekening behoort te houden met de belangen van de betrokken persoon en dat hij - als hij dat onvoldoende doet - een zorgplicht jegens die persoon kan schenden.

Een recent voorbeeld hiervan is een Arubaanse zaak die resulteerde in het arrest van de Hoge Raad van 17 mei 2019. ${ }^{21}$ Kort samengevat ging het in die zaak om een onderzoek van een accountantskantoor naar onregelmatigheden binnen een stichting bij de vergoeding van reis- en verblijfkosten. Het onderzoek richtte zich op de gedragingen van een hooggeplaatste werknemer van de stichting. De stichting verzocht de rechter om ontbinding van de arbeidsovereenkomst met deze werknemer, welk verzoek mede op grond van het rapport van het accountantskantoor werd toegewezen. De werknemer startte daarop een civiele procedure tegen het accountantskantoor, waarin hij schadevergoeding vorderde op grond van

21. HR 17 mei 2019, ECLI:NL:HR:2019:744 (Ernst \& Young/N). onrechtmatige daad. In die procedure kwam het hof tot het oordeel dat de handelwijze van het accountantskantoor in strijd was met de in Nederland geldende gedrags- en beroepsregels voor accountants, in het bijzonder ten aanzien van het bieden van hoor en wederhoor. Het hof nam de schending van de gedrags- en beroepsregels mee als relevante omstandigheid bij de vaststelling dat het accountantskantoor jegens de werknemer had gehandeld in strijd met hetgeen in het maatschappelijk verkeer betaamt. De Hoge Raad sanctioneerde dat oordeel, waarbij hij expliciteerde dat de voor accountants geldende gedrags- en beroepsregels niet alleen invulling geven aan de verantwoordelijkheden van de accountant jegens zijn opdrachtgever, maar ook aan de verantwoordelijkheid van de accountant om te handelen in het algemeen belang. De door de accountant in het maatschappelijk verkeer jegens een derde in acht te nemen zorgvuldigheid wordt dan ook mede bepaald door hetgeen die gedrags- en beroepsregels meebrengen, aldus de Hoge Raad.

Het tweede gevalstype waarin sprake kan zijn van een zorgplicht van de accountant jegens een derde bij de uitoefening van een niet-wettelijke taak, is wanneer het voor de accountant duidelijk is dat een van hem afkomstige rapportage een derde onder ogen zal komen en die derde zeer waarschijnlijk op die rapportage zal vertrouwen bij het nemen van een beslissing, bijvoorbeeld over een bepaalde transactie.

Dit is het gevalstype dat aan de orde is in de casus van het arrest van de Hoge Raad van 29 januari 2021, dat hierna in deze bijdrage centraal staat en waarover in hoger beroep werd geoordeeld door het gerechtshof Arnhem-Leeuwarden (locatie Arnhem). Het toeval wil dat ditzelfde hof (zij het locatie Leeuwarden) zich in een (tussen)arrest in 2015 al eens had gebogen over een andere casus van dit gevalstype. ${ }^{22} \mathrm{Bij}$ die gelegenheid had het hof al een duidelijk raamwerk geschetst voor de wijze waarop dit soort zaken kunnen worden beoordeeld. Dat (tussen)arrest van het hof uit 2015 bleef in cassatie overeind; de Hoge Raad deed die zaak af met toepassing van art. $81 \mathrm{Wet} \mathrm{RO} .{ }^{23}$ In de onderhavige zaak herhaalt het hof het eerdere door hem ontworpen raamwerk, dat in grote lijnen neerkomt op het volgende:

- Indien een accountant er rekening mee dient te houden dat derden zullen kennisnemen van zijn rapport en daar hun gedrag (mede) door zullen laten bepalen, en hij geen zorgplicht jegens deze derden wenst te aanvaarden, ligt het volgens het hof op de weg van de accountant om waarborgen te treffen teneinde te voorkomen dat die derden ten onrechte (dan wel een onjuiste) betekenis toekennen aan een door hem opgesteld rapport.

- Deze waarborgen kan de accountant bijvoorbeeld treffen door (1) in het rapport duidelijk te vermelden voor wie het rapport (alleen) bestemd is en dat het niet aan anderen (derden) ter beschikking mag worden gesteld, en die der-

22. Hof Arnhem-Leeuwarden 10 januari 2015, ECLI:NL:GHARL: 2015:348.

23. HR 6 december 2016, ECLI:NL:HR:2016:2876 (Accon). 
den geen betekenis kunnen toekennen aan het rapport, alsmede (2) door nauwkeurig te vermelden wat het doel is van het rapport en dat het niet voor andere doeleinden kan en mag worden gebruikt.

- Heeft de accountant zulke waarborgen getroffen, dan rust op hem in beginsel geen zorgplicht jegens derden, met dien verstande dat wanneer de accountant weet of behoort te weten dat het rapport - ondanks de door hem getroffen maatregelen - toch door derden zal worden gebruikt, of door de beoogde gebruiker(s) zal worden gebruikt voor een ander doel dan waarvoor het is bestemd, hij daar aanvullende maatregelen tegen moet treffen, bijvoorbeeld door de derde te waarschuwen, of bij de beoogde gebruiker te protesteren tegen het oneigenlijke gebruik dat van het rapport wordt of dreigt te worden gemaakt. ${ }^{24}$

In de casus die ten grondslag ligt aan het in deze bijdrage te bespreken arrest van de Hoge Raad van 29 januari 2021 heeft het hof dit raamwerk dus ook toegepast. ${ }^{25} \mathrm{Ik}$ zal deze casus nu eerst kort (gesimplificeerd) schetsen en weergeven tot welke beslissing het hof met toepassing van het hier geschetste raamwerk kwam. Vervolgens bespreek ik het daartegen gerichte cassatiemiddel, het advies van de advocaat-generaal en het arrest van de Hoge Raad zelf, waarna ik de betekenis van dat arrest zal duiden en daarbij enige observaties zal plaatsen.

\section{De zaak van het Sloepenbedrij $\mathrm{f}^{26}$}

\subsection{De casus en het hofarrest}

Het gaat in deze zaak om de overname van de aandelen in een bedrijf dat een onderneming voerde in de productie en verkoop van luxe motorsloepen (hierna: het Sloepenbedrijf). In opdracht van het Sloepenbedrijf hebben accountants verbonden aan een accountantskantoor de jaarrekeningen over de boekjaren 2000 en 2001 samengesteld. De samenstellingsverklaring van beide jaarrekeningen dateert van 30 juli 2002 . Daarnaast hebben de accountants de cijfers over de eerste helft van het boekjaar 2002 opgesteld, die op 19 augustus 2002 aan het Sloepenbedrijf werden toegezonden. Het gaat hier dus om werkzaamheden in de uitvoering van niet-wettelijke taken. Het accountantskantoor wist dat zijn rapportages zouden worden gebruikt in het kader van de voorgenomen overname door Kopers A van alle aandelen in het Sloepenbedrijf. Kopers A kochten deze aandelen met de bevoegdheid een nader te noemen derde aan te wijzen. De precieze datum van verkoop van deze aandelen aan Kopers A is niet duidelijk, maar de levering ervan vond plaats op 23 augustus en 19 september 2002 aan een door Kopers A aangewezen derde-entiteit. Op 14 juni 2002 en bij overeenkomst gedateerd 31 juli 2002 verwierven Kopers A (althans aan hen gelieerde entiteiten) al het onroerend goed waarin de onderneming van het Sloepenbe-

24. Hof Arnhem-Leeuwarden 10 januari 2015, ECLI:NL:GHARL: 2015:348, r.o. 3.10.

25. Hof Arnhem-Leeuwarden 25 juni 2019, ECLI:NL:GHARL: 2019:5245, r.o. 4.11.

26. HR 29 januari 2021, ECLI:NL:HR:2021:149 (Sloepenbedrijf). drijf werd gedreven respectievelijk de aan de sloepen gerelateerde intellectuele eigendomsrechten. Op 17 december 2002 hebben Kopers B een derde deel van de aandelen in het Sloepenbedrijf van Kopers A gekocht. Als in 2008 het Sloepenbedrijf failliet gaat, spreken zowel Kopers A als Kopers B de betrokken accountants tuchtrechtelijk aan. De tuchtrechter in hoger beroep (het College van Beroep voor het bedrijfsleven) oordeelt dat de accountants bij het samenstellen van de jaarstukken 2000 en 2001 en de halfjaarcijfers 2002 een beroepsfout hebben gemaakt en legt hun de maatregel van berisping op. Kort gezegd hadden de accountants vooruitbetalingen van klanten van het Sloepenbedrijf als resultaat geboekt zonder rekening te houden met de nog te verrichten prestaties, waardoor omzet werd toegerekend aan verkeerde periodes. Kopers A en Kopers B vorderen vervolgens in een civiele procedure van (onder meer) het accountantskantoor vergoeding van de schade die zij stellen te hebben geleden door de beroepsfouten van de accountants.

In hoger beroep wijst het gerechtshof Arnhem-Leeuwarden de vorderingen van beide groepen kopers af. Ten aanzien van Kopers A oordeelt het hof dat causaal verband ontbreekt, kort gezegd omdat zij al tot hun investering in het Sloepenbedrijf hadden besloten en aan die beslissing al voor een belangrijk deel uitvoering hadden gegeven voordat de jaarstukken 2000 en 2001 en de halfjaarcijfers 2002 beschikbaar kwamen. Dat is vooral een feitelijke kwestie, waartegen Kopers A in cassatie wel de nodige (motiverings)klachten richten, maar die de Hoge Raad met toepassing van art. 81 Wet RO afdoet.

De vordering van Kopers B wordt door het hof afgewezen op grond van het oordeel dat het accountantskantoor jegens Kopers B geen zorgplicht heeft geschonden. Daaraan legt het hof ten grondslag dat het accountantskantoor ten tijde van het uit handen geven van de cijfers aan het Sloepenbedrijf geen rekening ermee hoefde te houden dat de door de accountants opgestelde cijfers enige tijd na de aankoop van de aandelen in het Sloepenbedrijf door Kopers A ter beschikking zouden komen van opvolgende Kopers B en dat laatstgenoemden hun gedrag mede door die cijfers zouden laten bepalen. Op die beslissing gaat de Hoge Raad in cassatie wel inhoudelijk in. Centraal staat daarbij de vraag tot welke derden de zorgplicht van de accountant zich in een geval als dit uitstrekt.

\subsection{De vraag in cassatie: tot welke derden strekt de zorgplicht zich uit?}

In cassatie betogen Kopers B dat het hof heeft miskend dat, indien vaststaat dat de accountant wist of behoorde te weten dat zijn rapportage ter beschikking zou komen van derden die daarop zouden vertrouwen om een beslissing over een transactie te nemen, en er dus sprake is van een zorgplicht van die accountant jegens die derde, niet relevant is of de accountant weet of behoort te weten exact welke derden (zeer) waarschijnlijk op de rapportage van de accountant zullen vertrouwen bij het nemen van hun investeringsbeslissing. Bedoelde zorgplicht geldt dan jegens iedere derde, ongeacht of 
de accountant bij het uit handen geven van zijn rapportage met het bestaan of de identiteit van één specifieke derde reeds bekend is of behoort te zijn. Voor het ontstaan van de zorgplicht is slechts vereist dat de accountant ermee bekend is dat een derde op de rapportage zal gaan vertrouwen, aldus het relevante onderdeel van het cassatiemiddel. ${ }^{27}$

A-G Hartlief is van oordeel dat dit middel slaagt. In zijn motivering betrekt Hartlief een aantal elementen. Hij stelt voorop dat het voor de accountants duidelijk was dat het Sloepenbedrijf voorwerp van een investering of een overname zou worden en dat de (half)jaarstukken met het oog daarop werden opgemaakt. In een dergelijke setting moet het voor de accountants geen denkbeeldig scenario zijn geweest dat aanvankelijke belangstellenden zouden worden ingeruild voor of aangevuld met andere belangstellenden. Daarbij acht Hartlief het relevant dat Kopers B de (half)jaarcijfers hebben gebruikt voor hun investeringsbeslissing ten aanzien van aandelen in het Sloepenbedrijf en dus voor het doel waarvoor zij waren opgesteld. Dat deden zij in het laatste kwartaal van 2002 en daarmee in een periode waarin de cijfers nog recent en relevant waren. Van een derde met wie de accountants geen rekening hebben kunnen houden, is daarom geen sprake. Hartlief merkt daarbij op dat de accountants niet de hiervoor besproken - door het hof benoemde - maatregelen hebben getroffen om te voorkomen dat derden op hun rapportage zouden vertrouwen. Dit alles maakt volgens Hartlief dat het oordeel van het hof, dat beslissend is dat Kopers B pas in beeld kwamen nadat de accountants hun rapportage uit handen hadden gegeven, onjuist is. Hartlief voegt daar nog aan toe dat het hanteren van het moment waarop de accountant de stukken uit handen geeft weliswaar een zekere duidelijkheid geeft, maar ook leidt tot een willekeurige en inhoudelijk niet-reële begrenzing van de zorgplicht van de accountant. Het tijdstip van uit handen geven als zodanig is dan doorslaggevend, terwijl de kern moet zijn met het oog waarop de accountant de stukken heeft opgesteld, aldus nog steeds Hartlief. ${ }^{28}$

\subsection{Oordeel Hoge Raad}

De Hoge Raad volgt A-G Hartlief niet en verwerpt het cassatieberoep. Daarbij zet de Hoge Raad eerst het normatieve kader uiteen. In dat verband stelt hij voorop dat de vraag of een accountant bij de uitoefening van een niet-wettelijke taak jegens een derde heeft gehandeld zoals het een redelijk bekwaam en redelijk handelend vakgenoot betaamt, dient te worden beantwoord aan de hand van de omstandigheden van het geval. Daarbij moet mede acht worden geslagen op de functie van de accountant in het maatschappelijk verkeer. Indien de accountant gezien het belang dat een derde aan zijn rapportage zal hechten, ermee rekening moet houden dat die derde zijn gedrag mede door de inhoud van die rapportage laat bepalen, kan het nalaten maatregelen te treffen om te voorkomen dat die derde aan die rapportage ten onrechte of onjuiste betekenis toekent, in strijd zijn met hetgeen volgens ongeschreven recht in het maatschappelijk verkeer betaamt. ${ }^{29}$

Vervolgens past de Hoge Raad dit normatieve kader toe op deze zaak. Daarbij stelt de Hoge Raad dus voorop dat voor het antwoord op de vraag of de accountants jegens Kopers B een zorgplicht hadden, alle omstandigheden van het geval van belang zijn. Voor een bevestigend antwoord op die vraag volstaat niet dat de accountants jegens anderen - in dit geval Kopers A - een zorgplicht hadden omdat zij wisten of behoorden te weten dat hun rapportage ter beschikking van die anderen zou komen en dat die anderen daarop zouden vertrouwen om een beslissing over een transactie te nemen. Het rechtsklachtonderdeel van het cassatiemiddel faalt dus, omdat de daarin verdedigde rechtsopvatting in haar algemeenheid onjuist is, zo oordeelt de Hoge Raad. ${ }^{30}$

Ik versta dit oordeel aldus, dat het enkele feit dat een accountant weet of behoort te weten dat op zijn rapportage door een derde zal worden vertrouwd in het kader van een beslissing over een transactie, niet voldoende is om te concluderen dat die accountant daarmee een zorgplicht heeft tegenover alle derden die op dat rapport vertrouwen. Een dergelijke (te) algemeen gestelde regel kent ons rechtsstelsel niet.

De Hoge Raad volstaat echter niet met het afserveren van de in het cassatiemiddel - inderdaad - nogal algemeen geformuleerde rechtsopvatting. Hij oordeelt namelijk ook dat voor zover in het cassatiemiddel de klacht besloten ligt dat het hof ten onrechte heeft geoordeeld dat de accountants geen zorgplicht hadden jegens specifiek Kopers B, die klacht evenzeer ongegrond is. De Hoge Raad benoemt in dat kader eerst de relevante vaststaande feiten, te weten:

1. dat de (half)jaarcijfers waarom het in deze zaak gaat medio augustus 2002 door het accountantskantoor ter beschikking waren gesteld aan de directie van het Sloepenbedrijf;

2. dat in die periode Kopers A de aandelen in het Sloepenbedrijf hebben gekocht; en

3. dat pas in het laatste kwartaal van 2002 Kopers B als kopers van de - toen door de aan Kopers A gelieerde derde-entiteit gehouden - aandelen in het Sloepenbedrijf in beeld zijn gekomen.

Vervolgens geeft de Hoge Raad weer waar het oordeel van het hof op neerkomt, namelijk dat de accountants jegens Kopers B geen zorgplicht hebben geschonden, omdat zij ten tijde van het uit handen geven van de cijfers aan het Sloepenbedrijf geen rekening ermee hoefden te houden dat de door hen opgestelde cijfers enige tijd na de aankoop van de aandelen in het Sloepenbedrijf door Kopers A ter beschikking van opvolgende kopers als Kopers B zouden komen, en dat laatstgenoemden hun gedrag mede door die cijfers zouden laten bepalen. Dat

29. HR 29 januari 2021, ECLI:NL:HR:2021:149, r.o. 3.1.1.
30. HR 29 januari 2021, ECLI:NL:HR:2021:149, r.o. 3.2.2.
27. Weergave van het cassatiemiddel in HR 29 januari 2021, ECLI:NL:HR: 2021:149, r.o. 3.1.

28. Concl. A-G T. Hartlief, ECLI:NL:PHR:2020:746, nrs. 3.88-3.92. 
oordeel van het hof getuigt volgens de Hoge Raad niet van een onjuiste rechtsopvatting en is niet onbegrijpelijk. ${ }^{31}$

\section{Enkele beschouwingen naar aanleiding van het arrest}

Wat kunnen we hieruit nu afleiden? Ten eerste, dat de vraag jegens welke derden de accountant een zorgplicht kan hebben bij het afgeven van een rapportage in het kader van een nietwettelijke taak, afhangt van de omstandigheden van het geval. Het is naar haar aard - ik memoreerde het al eerder - dus een casuïstische kwestie.

Een belangrijke les is verder, dat een accountant die in het kader van een niet-wettelijke taak een rapportage afgeeft, er verstandig aan doet maatregelen te treffen om te voorkomen dat derden aan die rapportage ten onrechte of onjuiste betekenis toekennen. Dat klinkt als een open deur en dat is het misschien ook wel, maar het belang hiervan is met dit arrest wel onderstreept. Hoewel de Hoge Raad dat niet expliciet bevestigt, lijkt het erop dat het kan gaan om de concrete maatregelen zoals het hof die heeft geformuleerd en die hiervoor in paragraaf 2.3 zijn weergegeven. Een vraag is dan nog wel of de accountant met het treffen van deze maatregelen voorkomt dat hij een zorgplicht verkrijgt jegens een derde - dat was de benadering van het hof ${ }^{32}$ - of daarmee juist invulling geeft aan een bestaande zorgplicht. Het oordeel van de Hoge Raad dat het achterwege laten van de bedoelde maatregelen in strijd kan zijn met hetgeen in het maatschappelijk verkeer betaamt, lijkt op het laatste te duiden.

Omdat het zo casuïstisch is, kan in mijn optiek overigens ook niet als algemene regel uit het arrest worden afgeleid dat een accountant bij de uitoefening van een niet-wettelijke taak alleen een zorgplicht kan hebben jegens een derde van wie de accountant ten tijde van het uit handen geven van zijn rapport het bestaan kent. Het is dus op zichzelf niet uitgesloten dat een feitenrechter op grond van de specifieke omstandigheden van een geval kan oordelen dat een zorgplicht moet worden aangenomen tegenover een derde wiens identiteit bij het accountantskantoor nog niet bekend was ten tijde van het afgeven van de rapportage. Wel is duidelijk dat de feitenrechter grenzen kan - en mogelijk zelfs: moet - stellen aan wat voor de accountant voorzienbaar was, althans waarmee hij rekening moest houden. Het gaat te ver om - zoals A-G Hartlief in wezen bepleitte - van de accountant te verlangen dat hij rekening houdt met scenario's die in theorie denkbaar zijn over wat er met zijn rapportage kan gebeuren, maar waarvoor hij ten tijde van het uit handen geven van zijn rapportage geen concrete aanwijzingen heeft.

Het lijkt mij terecht dat dit niet van de accountant wordt verlangd. Een andersluidende opvatting zou hem in een moeilijke positie brengen. Waar zou het denken in scenario's dan

31. HR 29 januari 2021, ECLI:NL:HR:2021:149, r.o. 3.2.3.

32. Kritisch daarover is Y. Steeg-Tijms in haar noot in JOR onder het hofarrest (JOR 2019/271, nr. 8). immers moeten eindigen? Het ging nu om aandelen die Kopers A binnen enkele maanden aan Kopers B hadden doorverkocht, waarbij Kopers B ook de door de accountants opgestelde (half)jaarcijfers in handen kregen. Wat als Kopers B de aankoop van die aandelen hadden gefinancierd met een lening van de bank, waarbij de bank ook was afgegaan op die (half)jaarcijfers? ${ }^{33}$ En stel dat Kopers B een deel van die aandelen binnen enkele weken weer door zouden hebben verkocht aan Kopers C? Zo kan ik doorgaan en steeds zou de vraag rijzen: waar ligt de grens? Dat het hof die grens in deze zaak heeft getrokken bij de derden op wie de accountants concreet bedacht moesten zijn ten tijde van het uit handen geven van de (half)jaarcijfers, en dat dit op goedkeuring van de Hoge Raad kan rekenen, vind ik alleszins te billijken.

\section{Afsluiting}

Het is duidelijk dat de bijzondere rol die de accountant in onze maatschappij vervult ook bijzondere verplichtingen kan scheppen die, als de accountant daar niet goed mee omgaat, tot aansprakelijkheid kunnen leiden. Dat geldt ook jegens derden en niet alleen bij de vervulling van de taken waarvoor de accountant van de wetgever een monopolie heeft gekregen, maar soms dus ook daarbuiten. Dat is begrijpelijk, maar het is net zo begrijpelijk dat die aansprakelijkheid jegens derden in reikwijdte wordt begrensd. De sanctionering door de Hoge Raad van de wijze waarop de feitenrechter dat in deze zaak heeft gedaan, zegt iets, maar ook weer niet alles, omdat er zoveel ruimte is voor de weging van de concrete omstandigheden van het geval. De accountant die niet afhankelijk wil zijn van die weging door de feitenrechter, doet er verstandig aan waar mogelijk maatregelen te treffen om te voorkomen dat er op zijn rapport wordt vertrouwd door derden voor wie het rapport niet is bestemd, of dat er oneigenlijk gebruik van wordt gemaakt. 